«Reserch Note 》

\title{
Digestibility, Biological Value and 'Available' Lysine Content of some Protein Concentrates for Poultry
}

\author{
Jun-ichi OKUMURA and Iwao TASAKI
}

Laboratory of Animal Nutrition, Nagoya University, Nagoya

Considerable informations as to the value of a feed protein for animals can be obtained from a knowledge of amino acid composition. In some proteins, however, amino acid content which is chemically determined, may not be a true estimate of potential nutritive value. In the preimsent experiments, biological measures of protein quality, such as digestibility, biological value, and net protein value of 11 protein concentrates have been compared with the value of chemically analyzed 'total' and 'available' lysine.

\section{Materials and Methods}

Fifteen Single Comb White Leghorn cockerels, weighing 1.7 to $2.0 \mathrm{~kg}$ and attached with an artificial anus, were divided into 5 groups of 3 birds each, and they were given $80 \mathrm{~g}$ of pelleted experimental diets once a day. Some groups were used for 2 experiments. Composition of the experimental diets was shown in Table 1. Protein concentrates were replaced at the expense of corn starch to keep the diets isonitrogenous, although no attempt was made to make them isocaloric. These diets were adequate to

Table 1. Composition of experimental diets (\%)

\begin{tabular}{|c|c|c|c|c|c|c|c|c|c|c|c|}
\hline Diet & $\begin{array}{l}\text { Cotton- } \\
\text { seed } \\
\text { meal }\end{array}$ & $\begin{array}{l}\text { Fish } \\
\text { meal }\end{array}$ & $\begin{array}{c}\text { Fish } \\
\text { soluble } \\
\text { feed }^{11}\end{array}$ & $\begin{array}{l}\text { Corn } \\
\text { gluten } \\
\text { meal }\end{array}$ & $\begin{array}{l}\text { Peanut } \\
\text { meal }\end{array}$ & $\begin{array}{l}\text { Saf- } \\
\text { flower } \\
\text { meal }\end{array}$ & $\begin{array}{c}\text { Sesa- } \\
\text { me } \\
\text { meal }\end{array}$ & $\begin{array}{l}\text { Soy- } \\
\text { bean } \\
\text { meal }\end{array}$ & $\begin{array}{l}\text { Chlo- } \\
\text { rella }{ }^{2}\end{array}$ & $\begin{array}{c}\text { De- } \\
\text { fatted } \\
\text { chlo- } \\
\text { rella }^{2}\end{array}$ & $\begin{array}{l}\text { Pro- } \\
\text { tein } \\
\text { free }\end{array}$ \\
\hline Cornstarch & 52.67 & 64.50 & 45.81 & 64.08 & 61.03 & 23.31 & 53.39 & 57.62 & 62.11 & 55.98 & 81.65 \\
\hline Protein concentrate & 28.98 & 17.15 & 35.84 & 17.57 & 20.62 & 58.34 & 28.26 & 24.03 & 19.54 & 25.67 & 一 \\
\hline $\begin{array}{l}\text { Additional } \\
\text { ingredients }\end{array}$ & 18.35 & 18.35 & 18.35 & 18.35 & 18.35 & 18.35 & 18.35 & 18.35 & 18.35 & 18.35 & 18.35 \\
\hline Moisture & 8.6 & 9.4 & 10.5 & 10.1 & 10.0 & 8.5 & 9.8 & 11.6 & 9.7 & 9.8 & 11.6 \\
\hline Crude protein & 11.3 & 11.8 & 10.8 & 12.6 & 11.6 & 10.7 & 11.6 & 12.2 & 10.8 & 10.0 & 0.6 \\
\hline M.E. ${ }^{5)}(\mathrm{Cal} / 80 \mathrm{~g})$ & 265 & 294 & 255 & 292 & 280 & 226 & 281 & 277 & 281 & 285 & 305 \\
\hline \multicolumn{12}{|c|}{$\begin{array}{l}\text { 1) Fish-soluble feed is made of fish solubles and wheat bran as an absorber. } \\
\text { 2) Provided by Japan Chlorella Co. Ltd., Kunitachi, Tokyo. Defatted chlorella was made by extract- }\end{array}$} \\
\hline $\begin{array}{l}\text { 3) Supplies soybe } \\
\text { mixture } 1.22 \\
\text { 4) Nesheim et al. } \\
\text { 5) Calculated fro }\end{array}$ & $\begin{array}{l}\% \text { and } \mathrm{m} \\
\% \\
\text { 4) }\end{array}$ & $\begin{array}{l}\% \text {, almir } \\
\text { nineral } \\
\text { Feedstuf }\end{array}$ & $\begin{array}{l}\text { nium sili } \\
\text { mixture } \\
\text { ff Analys }\end{array}$ & $\begin{array}{l}\text { icate } 1 \% \\
5.63 \% \\
\text { sis Table }\end{array}$ & , powde & ered filte & r paper & $1.5 \%$, a & gar-agar & $1 \%$, vit & $\operatorname{tamin}$ \\
\hline
\end{tabular}

Received October 26, 1972 
maintain nitrogen equillibrium for the experimental birds (TASAKI and OKUmuRA ${ }^{11}$ ). The amounts of vitamins and minerals contained in the diets also covered the maintenance need for the experimental birds. The biological measure in linseed meal was not performed, because the birds refused to consume the linseed meal diets, and only lysine content was determined. After prefeeding of the experimental diets for 4 days, urine and feces were separately collected for the following 3 days. The experimental birds were subsequently fed a protein-free diet in the same regimen to determine endogenous urinary and fecal nitrogen excretion. During the experimental periods, the birds were allowed to drink water ad libitum. The experimental procedure and analytical method for urine and feces have been described in the previous paper ${ }^{1}$.

Acid hydrolysates of the test protein concentrates were evaporated and dissolved in sodium citrate buffer ( $\mathrm{pH} 2.2$ ) and 'total' lysine was determined chromatographically by means of the Beckman Model 120B amino acid analiser. 'Available' lysine was determined by the method of RAO et $\left.a l .^{2}\right)$.

\section{Results and Discussion}

The metabolic fecal nitrogen (MFN) and the endogenous urinary nitrogen (EUN) were determined with the cockerels used here. The mean value of 15 birds $\pm \mathrm{S}$. E. M. of the MFN was $57.5 \pm 3.4 \mathrm{mg} / \mathrm{kg}$ of body weight $/ 100 \mathrm{~g}$ of dry matter/day and that of the EUN was $103.1 \pm 8.3 \mathrm{mg} / \mathrm{kg}$ of body weight ${ }^{0.705} /$ day. Table 2 shows the true digestibility (TD) and the biological value (BV) of 10 protein concentrates. In poultry rations, protein content is usually indicated as crude protein but not digestible crude protein. Thus, it is useful to present the ratio of retained nitrogen to dietary nitrogen (net protein value; NPV) instead of the ratio of retained nitrogen to absorbed nitrogen (BV). NPV is also presented in Table 2.

The analytical results of 'total' and 'available' lysine of the test protein concen-

Table 2. True digestibility (TD), biological value (BV) and net protein valne (NPV) of 10 protein concentrates

\begin{tabular}{lcccccc}
\hline Protein concentrate & $\begin{array}{c}\mathrm{N} \text { intake } \\
(\mathrm{g} / \text { day })\end{array}$ & $\begin{array}{c}\text { Exogenous fecal } \mathrm{N}^{1)} \\
(\mathrm{g} / \text { day })\end{array}$ & $\begin{array}{c}\text { Exogenous urinary } \mathrm{N}^{2)} \\
(\mathrm{g} / \mathrm{day})\end{array}$ & $\begin{array}{c}\text { TD } \\
(\%)\end{array}$ & $\begin{array}{c}\text { BV } \\
(\%)\end{array}$ & $\begin{array}{c}\text { NPV } \\
(\%)\end{array}$ \\
\hline Chlorella & 1.37 & $0.29 \pm 0.02^{4)}$ & $0.37 \pm 0.02$ & $79 \pm 2$ & $65 \pm 3$ & 55 \\
Cottonseed meal & 1.44 & $0.16 \pm 0.02$ & $0.43 \pm 0.01$ & $78 \pm 1$ & $63 \pm 1$ & 49 \\
Defatted chlorella & 1.34 & $0.26 \pm 0.02$ & $0.48 \pm 0.02$ & $81 \pm 1$ & $46 \pm 1$ & 37 \\
Fish meal & 1.52 & $0.19 \pm 0.02$ & $0.25 \pm 0.03$ & $86 \pm 1$ & $81 \pm 2$ & 70 \\
Fish-soluble feed & 1.38 & $0.31 \pm 0.01$ & $0.25 \pm 0.02$ & $76 \pm 1$ & $77 \pm 1$ & 59 \\
Gluten meal & 1.61 & $0.07 \pm 0.01$ & $0.53 \pm 0.01$ & $94 \pm 0$ & $66 \pm 0$ & 62 \\
Peanut meal & 1.49 & $0.24 \pm 0.04$ & $0.75 \pm 0.02$ & $82 \pm 1$ & $39 \pm 1$ & 32 \\
Safflower meal & 1.38 & $0.26 \pm 0.01$ & $0.74 \pm 0.01$ & $80 \pm 0$ & $40 \pm 1$ & 32 \\
Sesame meal & 1.49 & $0.51 \pm 0.01$ & $0.54 \pm 0.01$ & $58 \pm 3$ & $44 \pm 1$ & 26 \\
Soybean meal & 1.57 & $0.20 \pm 0.02$ & $0.45 \pm 0.02$ & $85 \pm 1$ & $68 \pm 1$ & 57 \\
\hline
\end{tabular}

1) Total fecal $\mathrm{N}-$ Metabolic fecal $\mathrm{N}$

2) Total urinary $\mathrm{N}$-Endogenous urinary $\mathrm{N}$

3) $\mathrm{BV}(\%) \times \mathrm{TD}(\%) / 100$

4) Mean of 3 birds \pm S. E.M. 
Table 3. 'Total' and 'available' lysine content of 11 protein concentrates

\begin{tabular}{|c|c|c|c|c|}
\hline \multirow[t]{2}{*}{ Protein concentrate } & \multirow{2}{*}{$\begin{array}{l}\text { Protein content } \\
(\%)\end{array}$} & \multicolumn{2}{|c|}{$\begin{array}{l}\text { Lysine content } \\
\qquad(\mathrm{g} / 16 \mathrm{~g} \mathrm{~N})\end{array}$} & \multirow{2}{*}{$\frac{\text { 'Available' }}{\text { 'Total' }} \times 100$} \\
\hline & & 'Total' & 'Aailable' & \\
\hline Chlorella & 51.2 & 5.9 & 4.6 & 78 \\
\hline Cottonseed meal & 34.5 & 4.3 & 2.7 & 65 \\
\hline Defatted chlorella & 37.6 & 4.8 & 2.6 & 54 \\
\hline Fish meal & 58.3 & 9.5 & $6 \cdot 8$ & 72 \\
\hline Fish soluble-feed & 27.9 & 3.9 & 2.9 & 73 \\
\hline Corn gluten meal & 56.9 & 1.5 & 1.2 & 81 \\
\hline Linseed meal & 33.6 & 3.3 & 2.8 & 85 \\
\hline Peanut meal & 48.5 & 2.8 & 2.8 & 99 \\
\hline Safflower meal & 17.1 & 2.7 & 2.1 & 79 \\
\hline Sesame meal & 35.4 & 1.7 & 0.8 & 51 \\
\hline Soybean meal & 41.5 & 6.1 & 4.8 & 78 \\
\hline
\end{tabular}

trates were shown in Table 3. The ratio of 'available' to 'total' lysine (availability) was also shown in Table 3; being related to neither 'total' nor 'available' lysine content nor whether they were plant origin or animal origin.

Lysine is not always the limiting amino acid for retaining nitrogen, however, NPV was compared with chemically estimated 'available' lysine in 10 protein concentrates. A significant correlation, $r=0.648(\mathrm{P}<0.05)$, was found between the NPV and 'available' lysine content, which was rather higher than the correlation between the NPV and 'total' lysine content $(r=0.607,0.05<\mathrm{P}<0.1)$. The regression equation between the net protein value and 'available' lysine content was calculated as $\mathrm{Y}=54.8 \mathrm{X}+33.1$, where $\mathrm{Y}$ indicated the net protein value (\%) and $\mathrm{X}$ 'available' lysine content ( $\mathrm{g} / 16 \mathrm{~g}$ of $\mathrm{N}$ ). This result would show that chemically analyzed 'available' lysine reflected the biological utilizability of protein better than 'total' lysine. Boyne et al. ${ }^{3)}$ likely showed a high correlation between the content of 'available' lysine and the gross protein value in the diets for growing chicks.

\section{Aknowledgement}

The authors are grateful to Mr. Kiyoshi Furuy for his technical assistance on the determination of biological utilizability of chlorella.

\section{References}

1) Tasaki I. and J. Окumura: J. Nutr., 83, 34, 1964.

2) Rao, S. R., F. L. Carter and V.L. Frampton: Analyt. Chem., 35, 1927, 1953.

3) Boyne, A. W., K. J. Carpenter and A. A. Woodham: J. Sci. Food Agr., 12, 832, 1961.

4) Nesheim, M.C., J.D. Garlich and D. T. Hopkins: J. Nutr., 78, 89, 1962.

5) Hubbell, C. H.: Feedstuff, May 30, 18, 1970.

6) Tasaki, I., J. Okumura and K. Furuya: Japan Poultry Sci., 7, 37, 1962. 
奥 村 純市・田 先 威和夫

名古屋大学農学部

人工肛門を設着した白色レグホーン種の成鷂雄を用い て, 各種蛋白質飼料について, 消化率, 生物価および生 物学的に有効であるといわれている した“有効”リジン並びに“全”リジンにつき測定し た。蛋白質飼料としては, 魚粉, フィッシュソルブル, 大豆粕, 綿実粕, 亜麻仁粕, 落花生粕, サフラワー粕, ゴマ粕,グルテン, クロレラおよび脱脂クロレラを用い, 蛋白質含量約 $10 \%$ の半精製飼料劣作り実験に供した。

真の消化率および生物価は, 魚粉 86,81 ; 大豆粕 85 , 68 ; グルテン 94,66 ; フィッシュソルブル 76,77 ; 落花 生粕 82,$39 ;$ ，サフラワー粕 80,84 ; 綿実粕 78,63 ; ゴ マ粕 58,44 ; クロレラ 79,65 ; 脱脂クロレラ $81,46(\%)$ であった。

化学分析による蛋白質当りの “全” リジン量は, 魚粉, 大豆粕, クロレラ, 脱脂クロレラ, 綿実粕, フィッシュ ソルブル, 亜麻仁粕, 落花生粕, サフラワー粕, ゴマ粕, グルテンの順であったが, “有効”リジン量は, 魚粉, 大豆粕, クロレラ, フィッシェソルブル, 亜麻仁粕, 落
花生粕, 綿実粕, 脱脂クロレラ, サフラワー粕, グルテ ンゴマ粕の順となった。“全”リジン量に対する“有 効”リジン量の比は, “全”リジン量, “有効”リジン 量および蛋白質飼料が動物性であるか植物性であるかと は無関係であった。この比の最も高いのは落花生粕の 99\%であり，続いて亜麻仁粕の $85 \%$ であった。動物性 蛋白質である魚粉, フィッシュソルブルは比較的低い值 を示し，それぞれ72,73\%であった。また最も低い比率 はゴマ粕の $51 \%$ であった。

蛋白質飼料の正味蛋白質価（真の消化率×生物価）と “全”リジン量との間には有意な相関関係が得られなか ったのに対し, “有効”リジン量との間には有意な相関 関係 (相関関係 $r=0.648, p<0.05$ ) が得られた。これら の事実からも, “全”リジンより, “有効”リジンが飼 料蛋白質の生物学的有効性を示すことが分る。また，蛋 白質飼料の正味蛋白質価 (\%) を $\mathrm{Y}$, “有効” リジン量 $(\mathrm{g} / 16 \mathrm{~g} \mathrm{~N})$ を $\mathrm{X}$ とる, $\mathrm{Y}=5.48 \mathrm{X}+33.1$ の回帰式が 得られた。

（家禽会誌, 10, 37〜 40, 1973)

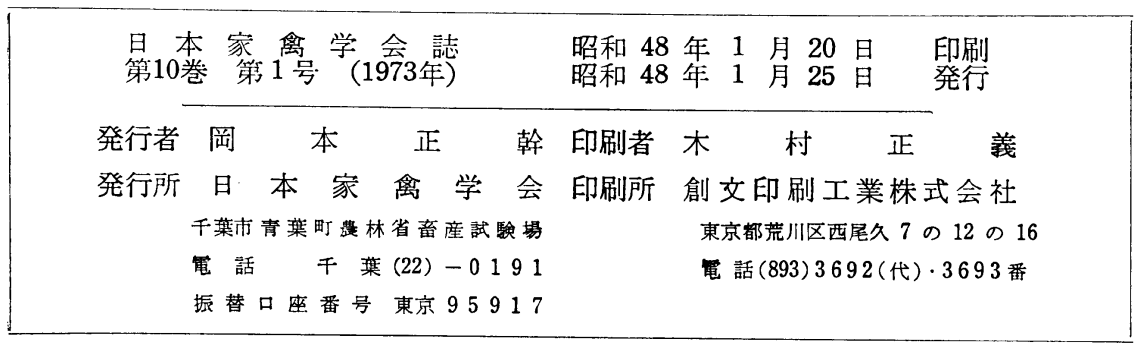

広告担当者 有限会社瀬戸広告社 東京都交京区本郷 1-22-1 電話 (812) 4310 - 6091 